\title{
Analisis Wakamono Kotoba Dalam Acara Televisi New World Land SMAPXSMAP
}

\author{
WISTRI MEISA \\ Program Studi Pendidikan Bahasa Jepang, Fakultas Pendidikan Bahasa \\ U niversitas M uhammadiyah Yogyakarta \\ wistri.meisa@umy.ac.id
}

\begin{abstract}
ABST RAK
Sifat bahasa yang arbitrer dan dinamis menjadi salah satu faktor penyebab merebaknya wakamono kotoba di satu lingkup masyarakat. Wakamono kotoba memiliki karakteristik bahasa tersendiri, terutama dari asal-usul pembentukannya yang berupa pemendekan kata. Makalah ini membahas mengenai arti dan pembentukan wakamono kotoba yang muncul dalam acara televisi New Word Land SmapxSmap.Tujuan penelitian ini adalah untuk mengetahui memahami cara pemendekan wakamono kotoba dan arti kata dari wakamono kotoba yang muncul pada objek penelitian tersebut. M etode yang digunakan dalam penelitian ini adalah metode deskriptif. Data yang muncul pada objek penelitian ditranskripkan kedalam tulisan lalu kemudian diidentifikasi serta diinterpretasikan berdasarkan arti dan proses pembentukan dari wakamono kotoba tersebut.Dari hasil analisis data diperoleh kesimpulan bahwa pembentukan daripada wakamono kotoba tidak terbatas pada pemendekan kata saja, tetapi juga terdapat beberapa kata yang memiliki pola pembentukan tersendiri, seperti pengkiasan dan simbol daripada kata aslinya ataupun penambahan mora/silabel sebagai penegasan kata. Adapun pemendekan kata yang terjadi pada umumnya adalah pelesapan silabel/mora hingga menjadi 3-4 suku kata seperti pada kata「カラオケのともだち」 menjadi「カラとも」. Sedangkan wakamono kotoba yang terbentuk dari pengkiasan salah satunya adalah「武田さん」yang bermakna「徽夜する」 dimana kata sebenarnya dihilangkan dan dikaitkan dengan nama seorang aktor yang memiliki nama bawah yang sama dengan kanji yang dimaksud (Takeda Tetsuya).
\end{abstract}

Kata kunci: Wakamono Kotoba, Ryakugo

\section{ABSTRACT}

The nature of language is arbitrary and dynamic, which both are become influential factors for the spread of slang language on society. Unexceptionally in Japanese language or to be known as wakamono kotoba. Wakamono kotoba have its own characteristics, especially for the origin of its words structure. This paper discussed about semantic and structure issue on wakamono kotoba that have been discovered in New Word Land SmapxSmap TV Show.The purpose of this research is to find out the meaning and the structures pattern of wakamono kotoba, such as its abbreviation system in forming the slang words, specifically on the words that showed up in the TV Show mentioned above. 
This research used descriptive methods as its research methods, where the data that arises on research will be transcribed, identified and interpreted based on the semantic and structure guide of wakamono kotoba. From the result of the data analysis, it has been observed that the structures pattern of wakamono kotoba is not limited to abbreviation only, but there are also a few words having a different pattern such as metaphor and symbolizing the lexical meaning of the word into another word. In addition, it is also discovered that some words were altered with an addition of prefix or suffix following the abbreviated words. This addition of mora/syllable into the word indicating an emphasis on the word itself. The common abbreviation that have been found in this research is mora/syllable subtraction left the word up to 3-4 syllables, such as the 9 syllables of「カラオケのともだち」 altered into 4 syllables of 「カラとも」. Meanwhile, wakamono kotoba that have been formed from a metaphor can be seen in「武田さん」 which has meaning

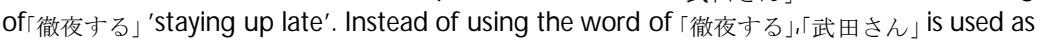
the owner of its name is a famous Japanese public figure「武田鉄矢」'Takeda Tetsuya' whose his first name pronounced the same as $0^{1}$ "Y $Y 0^{\prime}$ Tetsuya'. Therefore, in this case「武田さん」 symbolized as「徹夜する」 'staying up late'.

Keywords: Wakamono kotoba, abbreviaton, slang language

\section{PENDAHULUAN}

Bahasa merupakan alat komunikasi dalam keseharian kita yang bersifat dinamis, arbitrer atau mana suka. Hal ini juga diterangkan oleh M ulyati (2012:1), sehingga sifat daripada bahasa tersebut memungkinkan bahasa untuk mengalami perubahan yang men gakibatkan kean ekaragaman bahasa sesuai den gan latar belakang pengguna bahasa itu sendiri. Tentunya fenomena keanekaragaman bahasa ini berlaku bagi seluruh bangsa tidak terkecuali bahasa Jepang. M enurut C haer (2010:62), keanekaragaman atau variasi bahasa tersebut dapat terbentuk dari latar segi penutur seperti karakter, tempat tinggal, kedudukan sosial, jenis kelamin serta usia penutur tersebut. Senada dengan pendapat C haer, Sudjianto (2007) juga menyatakan bahwa salah satu faktor yang mempengaruhi keanekaragaman bahasa ini adalah faktor usia,

"bahwa di Jepang selain ragam bahasa standar (hyoojungo) terdapat pula berbagai macam dialek (hoogen), baik dialek regional (chihoogo atau chiikiteki hoogen), dialek sosial (shakaiteki hoogen), maupun dialek temporal (rekishiteki hoogen). D isebutkan pula bahwa berkaitan dengan dialek sosial, faktor usia juga sangat menentukan dalam keragaman bahasa Jepang, oleh karena itu di dalam bahasa Jepang terdapat ragam bahasa anak- 
anak (jidoogo atau yoojigo), bahasa anak muda (wakamono kotoba), dan bahasa orang tua (roojingo)." (Sudjianto dan A hmad Dahidi, 2007:17)

Bahasa anak muda (wakamono kotoba) merupakan bahasa atau ungkapan khusus yang digunakan oleh penutur antara usia 1030 tahun dalam kehidupan sehari-hari. Kata-kata yang muncul dalam wakamono kotoba ini sangat berkaitan erat dengan gaya hidup anak muda pada saat itu. Sehingga wakamono kotoba merupakan ragam bahasa yang dinamis yangakan sering berubah sesuai perkembangan jaman dan telah menjadi budaya dalam keseharian anak muda Jepang dalam berkomunikasi dengan sesamanya. $\mathrm{H}$ al ini tersirat pula dari pernyataan $\mathrm{H}$ arumi dalam Sudjianto (2007:23) yang mengemukakan bahwa terdapat kecenderungan anak-anak muda terus menerus menciptakan shingo dan ryuukoogo, dan mereka juga yang menjadi pelopor penyebaran bahasa tersebut. Dalam wakamono kotoba itu sendiri beliau menyebutkan bahwa keunikan dari bahasa tersebut seringkali menyebabkan penutur usia lanjut kesulitan untuk memahami kata tersebut.

Wakamono kotoba sendiri terbagi ke dalam beberapa jenis dan memiliki karakteristik yang khas. Di antaranya terdapat shingo dan ryuukoogo. A dapun karakteristik daripada wakamono kotoba tersebut adalah sebagai berikut.

1. Merupakan ragam lisan.

2. Biasa digunakan antara teman pada situasi non formal.

3. Dibuat dengan bebas tanpa memikirkan tata bahasa bahasa Jepang yang benar.

4. A danya penggabungan bahasa Jepang dan bahasa asing terutama yang berasal dari bahasa Inggris.

5. Adanya pemen dekan kata.

6. Penggunaan prefiks dan sufiks.

7. Adanya penggunaan dialog daerah tertentu.

Sementara itu Tanaka dalam Sudjianto (2007:24) menyim-

pulkan karakteristik wakamono kotoba adalah sebagai berikut. a) M enyingkat unsur-unsur kata/ kalimat (shooryaku); b) M embalik- 
kan urutan unsur-unsur kata (sakasa kotoba); c) M embuat verba dengan cara menambahkan silabel 'ru' atau 'tta' pada nomina; d) Mengungkapkan sesuatu dengan mengambil karakteristik manusia (jinbutsu zokugo).

Dari karakteristik yang telah dipaparkan di atas, terdapat karakteristik yang berupa pemen dekan kata. Pemendekan kata ini ditujukan untuk memudahkan pertukaran informasi secara efisien. Pada awalnya pemendekan kata tersebut digunakan untuk berkomunikasi antara anggota dalam suatu kelompok tertentu sebagai bahasa sandi yang bersifat rahasia. Namun seiring berjal an nya waktu, jumlah kosakatanya pun semakin bertambah dan berubah-ubah serta penggunaannya pun diketahui secara meluas oleh masyarakat umum. Sebagai contoh, kataケーワイ「空気読めない」 yang berarti tidak bisa membaca suasana danトウダイ「東京大学」 yang artinya U niversitas Tokyo, yang asalnya hanya digunakan oleh kelompok tertentu saja sekarang sudah digunakan secara luas.

Dari paparan di atas penulis dapat menyimpulkan bahwa wakamono kotoba merupakan salah satu komponen bahasa yang penting untuk diketahui bagi pembelajar bahasa Jepang asing. $\mathrm{Hal}$ ini dikarenakan wakamono kotoba tidak dipelajari secara khusus di dalam perkuliahan. Selain itu juga faktor populernya wakamono kotoba tersebut sebagai suatu bahasa yang umum digunakan juga menjadi salah satu pertimbangan. $\mathrm{H}$ al ini guna menghindari pembelajar bahasa Jepang asing tersandung masalah komunikasi ketika bersentuhan secara langsung dengan masyarakat Jepang.

O leh karena itu penulis berminat men eliti wakamono kotoba, yang dalam hal ini dikhususkan dalam segi pemendekan kata (ryakugo) yang diambil dari sebuah acara televisi yang berjudul "N ew W ord Land SmapxSmap". A dapun judul penelitian ini adalah "Analisis wakamono kotoba dalam acara televisi N ew Word Land 
SmapxSmap"

II. TINJAUAN PUSTAKA

Sebagaimana yang telah dipaparkan di bagian pendahuluan, bahasa memiliki sifat dinamis, arbitrer ataupun manasuka. Sifat daripada bahasa inilah yang menyebabkan terjadinya keanekaragaman bahasa yang tentunya dipengaruhi pula oleh latar belakang dari pengguna bahasa itu sendiri.

\section{PENGERTIAN WAKAMONO KOTOBA}

Seperti yang telah dijelaskan di bagian pendahuluan, bahasa anak muda (wakamono kotoba) merupakan bahasa atau ungkapan khusus yang digunakan oleh penutur antara usia 10-30 tahun dalam kehidupan sehari-hari. Kata-kata yang muncul dalam wakamono kotoba ini sangat berkaitan erat dengan gaya hidup anak muda pada saat itu. Sehingga wakamono kotoba merupakan ragam bahasa yang dinamis yang akan sering berubah sesuai perkembangan jaman dan telah menjadi budaya dalam keseharian anak muda Jepang dalam berkomunikasi dengan sesamanya.

Dalam ragam bahasa ini, penutur tidak memperhatikan tata bahasa Jepang yang benar melainkan bebas menciptakan sendiri bahasa yang digunakan. Selain itu, kata-kata dalam wakamono kotoba juga banyak yang berasal dari iklan televisi, drama dan ucapan-ucapan yang digunakan oleh tokoh publik yang menjadi populer dan digunakan dalam kehidupan sehari-hari. Wakamono kotoba biasanya digunakan terbatas pada kalangan terten tu tetapi ada juga ungkapan-ungkapan yang digunakan secara meluas.

\section{KARAKTERISTIK WAKAMONO KOTOBA}

Salah satu ciri atau karakteristik yang seringkali ditemukan pada wakamono kotoba adalah pemendekan kata. M enurut Tanaka dalam Sudjianto (2007:24), selain pemendekan kata, terdapat beberapa karakteristik lain yaitu,
a. Membalikkan urutan unsur-unsur kata (sakasa kotoba);
b. Membuat verba dengan cara menambahkan silabel 'ru' atau 'tta' pada nomina
c. Mengungkapkan sesuatu dengan mengambil karakteristik 
manusia (jinbutsu zokugo).

\section{FEN OMENA BAHASA GAU L DALAM BAHASA INDONE-}

\section{SIA}

Tidak jauh berbeda dengan fenomena wakamono kotoba dalam bahasa Jepang, fenomena bahasa gaul/ slang dalam bahasa Indonesia tidak dapat dihindari. $\mathrm{H}$ al ini disebabkan oleh daya kreatif masyarakat yang tinggi, yang menciptakan kosakata baru yang sulit dilacak pola pembentukannya. Selain itu, menurut Rosidi (2010) populernya bahasa gaul hingga kemudian berpotensi menjadi bahasa baku adalah karena bahasa gaul secara leluasa digunakan dan disiarkan melalui televisi. Senada dengan pendapat Rosidi, Mulyati (2012:04) juga berpendapat bahwa teknologi informasi mendukung populernya bahasa gaul terutama abreviasi pada kata tertentu. Adapun beberapa contoh pembentukan bahasa gaul dalam bahasa Indonesia yang pernah populer di antaranya adalah sebagai berikut ini:

a. U nsur penyingkatan, seperti ember yang disingkat dari emang bener; alay (anak layangan), dsb.

b. U nsur simbol, seperti tertera pada jargon salah satu operator ponsel indonesia, im3 itu mu24h.

c. Unsur fonologi, merubah bunyi huruf asli ke dalam logat sendiri seperti merit plis yang berasal dari married please.

Pola pemben tukan bahasa gaul di Indonesia umumnya banyak ditemukan unsur penyingkatan atau abreviasi. M eskipun, klasifikasi pembentukan kata menurut Kridalaksana (dalam M ulyati, 2010:4) sendiri dapat meliputi afiksasi, reduplikasi, komposisi (pemajemukan), abreviasi, metanalisis, derivasi balik, dan morfofonemik.

\section{ABREVIASI DALAM BAHASA JEPANG (RYAKU GO)}

Pada bagian pendahuluan telah dijelaskan bahwa pemen dekan kata (ryakugo) merupakan karakteristik daripada wakamono kotoba. $K$ ata ryakugo sendiri berarti abrreviation; singkatan atau kependekan.

Tanaka dalam Sudjianto (2007:24) memaparkan bahwa pembuatan shingo dengan cara menyingkat sebagian unsur seperti 
ini merupakan fenomena yang dilakukan juga oleh orang-orang pada umumnya, tidak terbatas pada anak-anak muda. Kata-kata yang relatif panjang yang sering dipakai pada kegiatan seharihari seperti noogyoo kyoodoo kumiai (koperasi pertanian) pada umumnya disingkat menjadi nookyoo untuk mempermudah pada saat mengingat dan memakainya. Tetapi, tujuan pemakaian singkatan dalam bahasa anak muda berbeda dengan yang dilakukan orang pada umumnya. A rtinya, yang merupakan karakteristik bahasa anak muda terletak pada kecenderungan anak muda yang ingin menyingkat bahasa atau kata-kata secara tidak hati-hati dengan 'perasaan main-main'.

Adapun contoh yang termasuk jen is ini adalah geesen (geemu sentaa = pusat permainan), getsudoramiru (getsuyoobi no dorama 0 miru $=$ nonton drama yang ditayangkan setiap hari Senin), dan makudo atau makku (makudonarudo $=M C D$ onald).

a. Pola pembentukan ryakugo

M enurut Kuwamoto (1998:27), salah satu pola pemendekan kata terjadi berdasarkan foot binarity dalam bahasa jepang, yang juga disebut bimoraic foot. M aksudnya adalah pemendekan berupa dua mora yan g diambil dari dua kata yang kemudian disatukan menjadi satu kata. Pola dan contohnya adalah sebagai berikut.

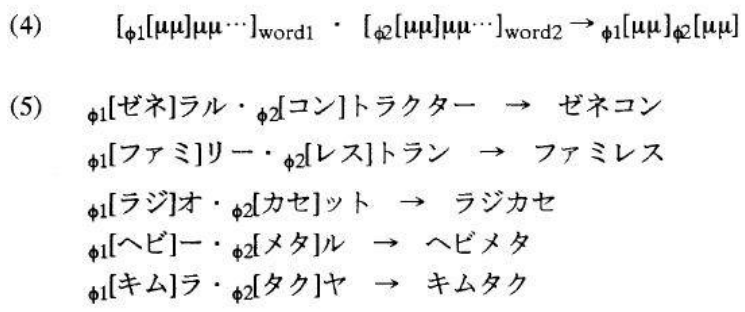

GAMBAR1 CONIOHPQAFEMENDEANKATABRDASAPKANBMCRACFCOT(A)

Dari pola di atas dapat disimpulkan bahwa pola yang dipakai merupakan pola 2-2, yaitu pengambilan 2 mora di kata pertama dan 2 mora di kata kedua yang kemudian disatukan.

Selain pola tersebut, terdapat pula pola pemendekan sebagai 
berikut.

a. ${ }_{\phi 1}[$ テレ]ホン・(カ)ード $\rightarrow$ テレカ ${ }_{\phi 1}[$ ポテ]ト・(チ)ップス $\rightarrow$ ポテチ

b. ${ }_{\phi 1}\left[\right.$ パくー>ソ]ナル・ ${ }_{\phi 2}[$ [コ]ピュータ $\rightarrow$ パソコン ${ }_{\phi 1}\left[\right.$ アメ]リカン・ ${ }_{\phi 2}[$ 「くくッ>トホボール $\rightarrow$ アメフト

GAMBAR2 CONIOHPQAPEMENDEKANKATABPDASAFKANBMORACFOT(B)

D ari pola (b) yangterjadi adalah pelesapan mora $\ulcorner-\lrcorner$ penanda chokuon dan sokuon「ッ」 pada kata yang umumnya terdiri dari 2 mora dan 1 silabel. Akan tetapi ada kalanya dalam keadaan tertentu berlaku pola dimana mora tersebut digunakan. Sebagai contoh pada berikut ini.

$$
\begin{aligned}
& { }_{\phi 1}\left[\text { ゲー]ム・ }{ }_{\phi 2}[\text { セン }] \text { ー } \rightarrow\right. \text { ゲーセン } \\
& { }_{\phi 1}[\text { パン]ティー・积[ストッキンダ } \rightarrow \text { パンスト } \\
& { }_{\phi 1}\left[\text { スケ]ート・ }{ }_{\phi 2}[\text { ボー]ド } \rightarrow \text { スケボー }\right.
\end{aligned}
$$

GAMBAR3. CONIOHPOAFEMENDEKANKATABRDASAFANBMMRACFOT(Q

Dari gambar 3 di atas dapat dilihat penggunaan mora $0^{-}$

Oyang dengan ini menunjukkan bahwa pola (c) termasuk ke dalam kategori 1 silabel kaki. D engan kata lain pengkategorian silabel kaki dalam bahasa Jepang ini terbagi atas 2 silabel 1 kaki dan 1 silabel satu kaki. Adapun pola ini terlacak dan mempengaruhi daripada pemendekan kata itu sendiri.

a. bimoraic-bisyllabic foot

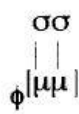

type: ${ }_{\phi}[(\mathrm{C}) \mathrm{V}(\mathrm{C}) \mathrm{V}]$ b. bimoraic-monosyllabic foot

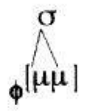

type: ${ }_{\phi}[(\mathrm{C}) \mathrm{VV}] /{ }_{\phi}[(\mathrm{C}) \mathrm{VC}]$ 
b. Fenomena wakamono kotoba

Sebagaimana telah dipaparkan pada bagian pendahuluan sebelumnya, sifat yang dimiliki bahasa, yakni kedinamisannya membuat fenomena bahasa tidak terelakkan. Seperti halnya dalam bahasa Indonesia, dalam bahasa Jepang pun pemendekan kata tidak selalu dibatasi oleh pola pembentukan secara resmi. Berdasarkan pernyataan oleh Tanaka dalam Sudjianto(2007:23) yang berbunyi "terdapat kecen derungan anak-anak muda terus menerus menciptakan shingo dan ryuukoogo, dan merekajuga yang menjadi pelopor penyebaran bahasa tersebut", maka dapat diasumsikan bahwa terdapat in dikasi terjadinya perubahan secara terus menerus berkenaan wakamono kotoba.

\section{METODE PENELITIAN}

M etode yang digunakan dalam penelitian ini adalah metode deskriptif, yaitu menjelaskan suatu keadaan atau fen omena secara apa adanya dengan jalan mengumpulkan data, menyusun dan men gklasifikasikan, menganalisa, dan menginterpretasikannya. M etode ini digunakan untuk menjelaskan dan menggambarkan fenomena yang terjadi secara ilmiah untuk menjawab permasalahan yang akan dibahas.

\section{TEKNIK PENGU MPU LAN DATA}

a. Studi pustaka, yaitu menghimpun, men eliti dan mempelajari sumber yang bersangkutan dengan masalah yang akan dibahas. Dalam penelitian ini literatur yang digunakan antara lain adalah buku-buku referensi, kamus, skripsi-skripsi yang berkaitan dengan penelitian yang penulis lakukan, serta beberapa sumber lainnya yang didapatkan melalui internet.

b. O bservasi, yaitu pengamatan dan pencatatan serta sistematis atas fenomena-fenomena yang diteliti. Pada penelitian ini penulis melakukan pengamatan terhadap wakamono kotoba yang digunakan dalam acara televisi "N ew Word Land SmapxSmap". Adapun episode yan g dijadikan objek penelitian adalah dua episode yan g ditayan gkan pada 2 N ovember 2009 dan 25 Desember 2010. Pemilihan episode tersebut adalah 
karena tema pada episode tersebut sesuai dengan tema penelitian ini, yaitu tentang wakamono kotoba. Pencatatan tersebut adalah membuat transkip kosakata wakamono kotoba yang muncul sebagai korpus data penelitian.

\section{LANGKAH PENELITIAN}

Berikut ini adalah langkah-langkah yang dilakukan dalam menganalisis data pada penelitian ini.

a. M engumpulkan contoh wakamono kotoba yang muncul dalam acara televisi "N ew Word L and SmapxSmap" dengan cara mentranskripkannya kedalam tulisan.

b. M engelompokan kata sesuai dengan jen is kata dan penggunaannya.

c. Mengkaji kosakata yang muncul untuk diteliti arti, makna dan cara pembentukannya.

d. M enyimpulkan hasil yangtelah diperoleh setelah melakukan semua proses pengolahan data.

TAEH 1 WAKAMONOKOIOBADALAMNEMVRDLANDSMPXSMPP

\begin{tabular}{|c|c|c|c|c|}
\hline 動詞 & 名詞 & 複合名詞 & 固有名詞 & その他 \\
\hline もそる & ロデ男 & ミートグッパイ & ハムト & NHK \\
\hline トラグル & マショ子 & 逆コナン & 武田さん & むりーム \\
\hline タヒる & バッキー & キリバネ & & ¥ジェル \\
\hline ペコる & & アイキャンディ & & \\
\hline くまる & & カニカマ & & \\
\hline 与謝野る & & カラ友 & & \\
\hline \multirow[t]{3}{*}{ 赤る } & & ひがも & & \\
\hline & & 一きゅうん & & \\
\hline & & イタ告 & & \\
\hline
\end{tabular}

\section{PEMBAHASAN HASIL PENELITIAN}

Berikut adalah korpus wakamono kotoba, yakni shingo yang digunakan dalam acara televisi "N ew World Land SmapxSmap". D ata yang didapat dicatat dan dikategorikan ke dalam beberapa jenis kata berdasarkan penggunaan kata tersebut dalam kalimat. Total kata yang didapat adalah sebanyak 24 kata dan digolongkan 


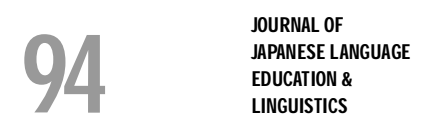

dalam kelas kata D oushi, M eishi, Fukugomeishi, Koyuumeishi dan kategori lain. Korpus data tersebut disajikan pada tabel 1.

Korpus tersebut kemudian dianalisis dan dideskripsikan mulai dari arti/ makna kata, kata asal, pembentukan pemendekan kata hingga contoh penggunaan kata tersebut di dalam kalimat. Berikut adalah analisa deskripsi daripada kata tersebut.

1.カラ友 : いっも一緒にカラオケに行く友達

(KARAokenoTO M O dachi)

Arti/ makna kata: teman karaoke

Padakata ini pemendekan kata dilakukan dengan menghilangkan silabel [0], [ke] dari karaoke dan kanji [dachi] pada [tomodachi]. Kata awal yang memiliki 9 suku kata ini setelah mengalami pemendekan berubah menjadi 4 suku kata.

Contoh Kalimat:

「俺さあカラ友多いからさあ明日夜さあ行っちやおうぜ!」

0 resaa,karatomo ooi karasaa, getsubiyorusaa, icchaouze!

A ku ya, karena banyak teman karaoke, senin malam nanti pergi yuk!

(N ew World Land SmapxSmap, aired N ovember 2,2009)

2. 赤る：赤外線通信を使って電話番号とメールアドレスを交換

すること

(SEKIgaitsuushin)

Arti/ makna kata: bertukar alamat email dan nomor telepon menggunakan data komunikasi infrared.

Pada kata ini pemendekan kata dilakukan dengan hanya men gambil kanji pertama [seki] dan kata lanjutan diganti oleh silabel [ru]. Kata awal yang memiliki 10 suku kata ini setelah pemendekan kata berubah menjadi 3 suku kata.

Contoh kalimat:

「私香取さんと仲良くなりたいんで赤りたいです」

Watashi, $K$ atori-san to nakayokunaritainde, sekiritai desu

Karena saya ingin berteman baik dengan Katori, saya ingin bertukar nomor telepon 
(N ew World Land SmapxSmap, aired November 2,2009)

\section{3.ひがも:「被害妄想」の略 (HIGAiM ousou)}

Arti/makna kata: singkatan dari higai mousou, yang berarti delusional disorder atau berhalusinasi.

Pada kata ini pemendekan kata dilakukan dengan menghilangkan silabel [i] pada [higai] dan silabel [u] serta [so] pada [mosou]. Kata yang pada awalnya memiliki 7 suku kata setelah mengalami pemendekan kata berubah menjadi 3 suku kata.

Contoh kalimat:

「えっていうか私そこまで言ってなくない?

\section{あんたのひがもだよそれ!」}

Ee,tteiuka watashi sokomade ittenakunai? E e? A nta no higamodayo sore!

$\mathrm{H}$ ah? Emang aku ngomong kayak gitu? $\mathrm{H}$ ah? Itu sih halusinasi kamu saja kali

(N ew World Land SmapxSmap, aired November 2,2009)

4.いちきゅん：一目惚れ

Arti/M akna kata: jatuh cinta pada pandangan pertama

Pada kata ini pembentukan kata dilakukan dengan menghilangkan dua kanji akhir [me] dan [bore] kemudian diganti dengan satu kata [kyun], sebagai kiasan debaran jantung ketika jatuh cinta. Setelah proses modifikasi, kata jumlah suku kata berubah menjadi 4 suku kata.

Contoh kalimat:

「実は前に会った時に黒沢にいちきゅんしたんだ！」

Jitsu wa maeni atta toki ni kurosawa ni ichikyun da!

Sebenarnya waktu pertama kali bertemu, sayajatuh cinta pada pandangan pertama sama Kurosawa!

(N ew World Land SmapxSmap, aired November 2,2009)

5.むりーム: 叶えられない夢。無理な夢 (MURInayume)

Arti/makna kata: impian yang mustahil. 
Padakata ini pemendekan kata dilakukan dengan menghilangkan silabel [na] pada [murina] dan kanji akhir [yume] diubah ke dalam bahasa inggris [doriimu], kemudian dilesapkan dan hanya diambil mora [-] dan silabel [mu]. Kata yang pada awalnya memiliki 5 suku kata setelah mengalami pemendekan kata berubah menjadi 4 suku kata.

Contoh kalimat:

「あなた最近体重が増えたから、になるのはむりームよ!

A nata saikin taijuu ga fuetakara, ni naru no wa muriimu yo!

Karena kamu belakangan ini berat badannya nambah, jadi itu mustahil tahu!

(N ew World Land SmapxSmap, aired N ovember 2,2009)

6. ¥ジェル: やたらとお金のかかる女性。「エンジェル」

(Angel)のもじり

Arti/makna kata: perempuan yang menyukai uang (gaul:

cewek matre)

Pada kata ini pembentukan kata terjadi dengan mengganti silabel [e] dan [n] pada [enjeru] dengan simbol [en]. Padakata ini tidak terdapat perubahan jumlah suku kata setelah mengalami pemendekan kata.

Contoh kalimat:

$$
\text { 「アイツってもう信じらんねえぐらい¥ジェル」 }
$$

A itsu tte mou shinjirannee gurai enjeru

Dia tuh kebangetan banget matrenya

(N ew World Land SmapxSmap, aired N ovember 2,2009)

7. バッキー: 恋人に対して束縛のきつい人。「束バッキー」と同語

Arti/makna kata: posesif, orang yang sangat mengekang kekasihnya.

Pada kata ini pemendekan kata dilakukan dengan menghilangkan kanji [soku] dan silabel [ku] pada [baku], kemudian diganti menjadi [kkii]. Kata yang pada pada awalnya memiliki 4 
suku kata berubah menjadi 3 suku kata.

Contoh kalimat:

俺顔はこうやってさらっとして見えるかもしれないけ

ど君に対してバッキーだから」

0 re, kao wa kou yatte saratto shite mieru kamoshirenaikedo, kimi ni taishite bakkii dakara

A ku mukanya mungkin keliatan lempeng kayak gini, tapi kalo soal kamu aku orangnya posesif

(N ew World Land SmapxSmap, aired November 2,2009)

8. イタ告：いたずらな告白。好きでもない人に「好きです。付き合っ

ってください」と告白すること。

(ITAzuranaKOKU haku)

Arti/ makna kata: pernyataan suka palsu. M engatakan suka dalam artian bercanda.

Pada kata ini pemendekan kata dilakukan dengan menghilangkan silabel [zu], [ra] dan [na] pada [itazurana] dan juga menghilangkan kanji [haku] pada kanji [kokuhaku]. Kata yang pada awalnya memiliki 9 suku kata ini berubah menjadi 4 suku kata.

Contoh kalimat:

「イタ告したんだけど、でも本当は本気なんだよね！」 Itakokushitandakedo, demo hontou wa honkinandayone! Kamu pura-pura nembak, tapi sebenernya beneran kan ya! (N ew World Land SmapxSmap, aired November 2,2009)

9.もそる : 妄想する (M ouSO usuRU)

Arti/makna kata: membayangkan atau mengkhayalkan sesuatu.

Pada kata ini pemendekan kata dilakukan dengan menghilangkan silabel [u] pada [mou] dan [sou] serta silabel [su] pada [suru]. Kata yang pada awalnya memiliki 7 suku kata ini setelah mengalami pemendekan kata berubah menjadi 3 suku kata. 
Contoh kalimat:

「昨日の夜も今日お前に会えると思ってお前のことをもそちゃった」

$\mathrm{K}$ inou no yoru mo ima mo omae ni aeru to omotte, omae no koto 0 mosochatta

Karena semalam mikirin hari ini bisa ketemu kamu, aku jadi kebayang-bayang soal kamu

10.ロデ男：女性にふりまわせる男 (RODEOOTOKO)

Arti/ makna kata: laki-laki yang selalu menurut pada wanita.

Pada kata ini pemendekan kata dilakukan dengan menghilangkan silabel [0] pada [rodeo]. kata yan g awal nya memiliki 6 suku kata berubah menjadi 5 suku kata setelah mengalami pemendekan kata.

Contoh kalimat:

オレさあ結局ダメなんだよね。いつもロデ男なんだよ。

負けちゃうんだよ㸚女にさあ」

0 resaa, kekkyoku damenandayone. I tsumo rodeo nandayo. $M$ akechaundayone onna ni saa

A ku emang payah ya. Selalu saja nurut sama perempuan. Pasti kalah deh sama perempuan (N ew World Land SmapxSmap, aired N ovember 2,2009)

11. ミートグッバイ：肉離れ・ミートグッドバイ

Arti/ makna kata: kram otot

Pada kata ini pemendekan kata dilakukan dengan menghilangkan silabel [do] pada [guddobai]. Kata yang awalnya memiliki 7 suku kata setelah mengalami pemendekan kata menjadi 6 suku kata.

Contoh kalimat:

「私って昔からテニスしてて、ナブラチロワって言われてたんだけど、

よくコートの中で走りすぎて、あ〜ミートグッバイ

Watashi tte mukashi kara tenisu shitete, naburachirowa tte 
iwaretetandakedo, yoku kooto no naka de hashirisugite, aa miitogubbai

A ku dari dulu main ten is sampai sering dibilang seperti $N$ avracherov (nama atlet), tapi karena terlalu bersemangat lari di lapangan, aa!! K ram otot

12. 逆コナン：コナンの逆。みためは大人ですが、 中には子供だということ。

Arti/makna kata: penampilan terlihat dewasa namun karakternya masih seperti anak-anak.

Pemendekan kata dilakukan dengan menghilangkan silabel [no] dan posisi kata daripada [gyaku] dan [konan] dibalik. Kata yang awalnya memiliki 6 suku kata ini berubah menjadi 5 suku kata setelah mengalami modifikasi.

Contoh kalimat:

「前から思ってんだけど直美って逆コナンじゃない」

$\mathrm{M}$ ae kara omottendakedo, $\mathrm{N}$ aomi tte gyaku konan janai

Dari dulu kepikiran, Naomi tuh kebalikannya konan ya

(N ew World Land SmapxSmap, aired November 2,2009)

13.とらぐる: トライアングル。三角関係 (TORAianGURU)

Arti/ makna kata: cinta segitiga

Pemendekan kata dilakukan dengan menghilangkan silabel [i], [a], [n] pada [toraianguru]. K ata yang awalnya memiliki 6 suku kata berubah menjadi 4 suku kata setelah mengalami pemendekan kata.

Contoh kalimat:

「僕、あの子と付き合ってたんだけど、もう一，

人好きな子ができちゃってトラグルっちゃってんだよ拜

Boku, ano ko to tsukiatetadakedo, mou hitori sukina ko ga dekichatte, toragurucchatendayone

A ku pacaran sama dia, tapi aku jadi suka sama orang lain, jadinya ya cinta segitiga

(N ew World Land SmapxSmap, aired November 2,2009) 
14. マショ子 : 魔性の女の子（あやしい魔女のよう

な女の子) (MASHO unoonnanoKO)

Arti/ makna kata: perempuan yang misterius

Pemendekan kata dilakukan dengan menghilangkan silabel [u] pada [mashou] dan menghilangkan partikel [no] serta kanji [onna]. Pada kata yang awalnya memiliki 9 suku kata ini berubah menjadi 3 suku kata setelah mengalami pemendekan kata.

Contoh kalimat:

「直美ってオレ思うんだけどマショ子でしょ」

$\mathrm{N}$ aomi tte ore omoundakedo, mashoko desho

Naomi tuh, aku pikir misterius deh

(N ew World Land SmapxSmap, aired N ovember 2,2009)

15. タヒル : 死ぬ（絶望の意味）

Arti/ makna kata: tewas, putus asa, tamat riwayat.

Pada kata ini terdapat perubahan bentuk yang diambil daripada unsur yang membentuk kanji [shi] menjadi silabel [ta] dan [hi], kemudian disisipkan silabel [ru] pada akhir kata. Jumlah suku kata yang terdapat pada kata ini adalah 3 suku kata.

Contoh kalimat:

「あ〜俺もうだめだよ。こんなバルーンが壊れちや

ったらタヒルよ」

A a ore mou damedayo. Konna baruun ga kowarechattara tahiruyo Aduh aku udah nggak kuat nih. Kalau balon kaya gini pecah, mati deh.

(N ew World Land SmapxSmap, aired N ovember 2,2009)

16.ペコる：ペコペコ。お腹がすいたパコペコ (PEKO peko) 
Arti/ makna kata: lapar.

Pemendekan kata dilakukan den gan menghilangkan satu kata [peko] dan penambahan silabel [ru] di akhir kata. Pada kata yang awalnya memiliki 4 suku kata ini setelah men galami pemendekan kata berubah menjadi 3 suku kata.

Contoh kalimat:

「ああ俺、朝からずっと働いてて何も口に入れてな

からさあペコってんだよね」

A a ore, asa kara zutto hataraitete nanimo kuchi ni iretenaikarasaa pekottendayone

Aah aku dari pagi kerja terus, nggak makan apa-apa jadi kelaparan nih

(N ew World Land SmapxSmap, aired November 2,2009)

17. キリバネ : 切羽詰まっている (状態)

Arti/ makna kata: panik

Pemendekan kata dilakukan dengan menghilangkan kata akhir [tsumatteiru] dan mengubah bentuk huruf ke dalam katakana. Kata yang awalnya memiliki 9 suku kata ini berubah menjadi 4 suku kata setelah mengalami pemendekan kata.

Contoh kalimat:

「たくやがどんどんこっち来るから私今キリバネ詰まっちやった」

Takuya ga dondon kocchi kurukara watashi ima kiribane tsumacchatta

Gara-gara Takuya datang semakin dekat ke sini aku sekarang jadi panik

(N ew World Land SmapxSmap, aired January 25,2010)

18.くまる: 熊のようにずっと寝たい・パンダの目のように。寝不足

Arti/makna kata: kurang tidur. Kantung mata menghitam seperti mata beruang panda.

Pemendekan kata dilakukan dengan mengkiaskan [nebusoku] terlebih dahulu ke dalam kata [kuma] dan kemudian ditambah silabel [ru]. Kata yang awalnya memiliki 4 suku kata ini berubah 
menjadi 3 suku kata setelah pemendekan.

Contoh kalimat:

「ああ〜昨日も一昨日も寝てないから俺、今くまってるでしょう」

Aa kinoumo ototoi mo netenai kara ore, ima kumatteru deshou

Aah dari kemarin dan kemarin lusa aku nggak tidur, sekarang pasti hitam kaya mata beruang panda deh

(N ew World Land SmapxSmap, aired N ovember 2,2009)

\section{9.アイキャンディ: 目に甘い（かわいい）。目においしい}

Arti/ makna kata: keren, manis, enak dipandang mata.

Pemen dekan kata dilakukan dengan menghilangkan partikel [ni] dan mengganti [me] dan persamaan [amai] ke dalam bahasa inggris. Jumlah suku kata tidak mengalami perubahan baik sebelum maupun sesudah pemendekan kata.

Contoh kalimat:

「俺にとってあんまりにもちょっとレオタード姿がアイキャンディ

0 re ni totte anmarinimo chotto reotaado sugata ga aikyandi

Buat aku gaya leotard itu keren

(N ew World Land SmapxSmap, aired N ovember 2,2009)

20. 八ムト: 公衆便所/ 公 (八ム) トイレ（ト）

Arti/ makna kata: toilet umum

Pemendekan kata dilakukan dengan menghilangkan kanji [koushuu] dan menyetarakan kata [bensho] ke dalam [toire]. Kemudian dibentuk kata baru berdasarkan karakter kanji [kou] yaitu silabel [ha] dan [mu] sebagai pemendekan kata dari [koushuu]. Pada kata [toire] pun terjadi penghilangan silabel [i] dan [re]. Pada kata yang awalnya memiliki 7 suku kata ini setelah mengalami pemendekan kata menjadi 3 suku kata.

Contoh kalimat:

「マジヤバイ! 超おなか痛いわ! ちょっと駅前の八ムト寄っ

ていい?ああ...もうダメだだめだダメだ」

M aji yabai!chou onaka itaiwa!chotto ekimae no hamuto yotteii?

Aa..mou dameda dameda dameda 
G awat!! Sakit perut banget nih! M ampir dulu di toilet umum depan stasiun sebentar ya? Aduh udah nggak tahan, nggak tahan

(N ew World Land SmapxSmap, aired N ovember 2,2009)

21. NHK:なんか変な感じ (Nanka Henna Kanji)

Arti/ makna kata: aneh, canggung.

Pemendekan kata dilakukan dengan mengubahnya ke dalam romaji. [nanka] untuk ( $\mathrm{N}$ ), [henna] untuk $\mathrm{H}$, dan [kanji] untuk K. U ngkapan yangterdiri dari 9 suku kata ini setelah mengalami pemendekan kata berubah menjadi 3 suku kata.

Contoh kalimat:

「やっぱりこうやってずっと近くになってるとNHKになっちゃうよ」 Yappari kouyatte zutto chikaku ni natteruto N H K ni nacchauyo

Ternyata memang kalau terus-terusan deketan kayak gini jadi aneh loh

(N ew World Land SmapxSmap, aired November 2,2009)

22. 武田さん：徹夜すること

Arti/ makna kata: bangun sepanjang malam (begadang)

Pemendekan kata dilakukan dengan menghilangkan kata sebenarnya dan dikaitkan dengan nama seorang aktor yang memiliki nama bawah yang sama dengan kanji yang dimaksud (takeda tetsuya).

Contoh kalimat:

「私昨日からですね。朝から晚までずーと忙しくて、私武田さんなんですよ」

Watashi kinou kara desune. A sa kara ban made zuuto isogashikute, watashi takeda-san nan desuyo

Aku dari kemarin ya, dari pagi sampai malam sibuk terus, jadi begadang loh

(N ew World Land SmapxSmap, aired November 2,2009)

23. 与謝野る：かみが乱れる。

Arti/ makna kata: rambutnya menjadi berantakan. 
Pembentukan kata dilakukan den gan mengkiaskan kata [kami ga midareru] dengan nama seorang novelis [yoshano] yang menulis suatu novel berjudul [midarekami] kemudian menambahkan silabel [ru] di akhir kata. Kata yang awalnya memiliki 7 suku kata setelah mengalami pemendekan berubah menjadi 4 suku kata.

Contoh kalimat:

「私のご自慢のストレートな部分がですね。あなたのメイクラブのおか げで与謝野ってますよ」

Watashi no gojiman no sutoreetona bubun desune. A nata no meikurabu no okage de yosanottemasuyo

Rambut lurusyang aku banggakan ya, gara-gara makelovekamu jadi berantakan loh

(N ew World Land SmapxSmap, aired N ovember 2,2009)

24.カニカマ: 蟹にかまれること (KAN IniKAM Areru)

Arti/ makna kata: digigit oleh kepiting/ digigit oleh sesuatu

Pemen dekan kata dilakukan dengan menghilangkan partikel [ni] dan menghilangkan silabel [re] dan [ru] pada [kamareru]. $K$ ata yang pada awalnya memiliki 7 suku kata berubah menjadi 4 suku kata setelah mengalami pemendekan kata.

Contoh kalimat:

ブーンブーンブーン ...ああふざけんなよ! まったくもうカニカマ」

Buun buun buun...aa fuzakennayo! M attaku mou kanikama N guung nguung nguung...aa sebel! A mpun deh digigit (N ew World Land SmapxSmap, aired N ovember 2,2009)

Untuk lebih detailnya, hasil analisis data di atas dipaparkan dalam tabel 2.

\section{SIMPULAN DAN REKOMENDASI}

\section{SIMPU LAN}

Dari hasil analisis data di atas, diperoleh kesimpulan sebagai berikut.

a. Kata dan ungkapan yang muncul pada bangumi $\mathrm{N}$ ew Word 
Land SmapxSmap ini pada umumnya dipendekkan menjadi 34 suku kata meskipun ada beberapa yang tidak jauh berbeda dari jumlah suku kata aslinya (sekitar 5-6 suku kata), dan bahkan ada yang tidak berubah, seperti[アイキャンディ] $d a n$ [¥ジェル]

b. Tidak semua kata mengikuti pola pembentukan yang telah ada seperti yang dipaparkan oleh Kuwamoto (1998). Sebagian kata memiliki pola pembentukan tersendiri.

c. Sebagian besar pemendekan kata dilakukan dengan mengambil 2 mora pertama dari 1 kata dan menghilan gkan silabel lainnya. Salah satu contohnya adalah [karatomo] --> KARAoke no TO MO dachi

d. Selain pemendekan dengan pengambilan silabel/mora awal dan pelesapan silabel/ mora akhir, terdapat pula penghilan gan silabel/mora awal dan penggantian silabel/mora akhir. Sebagai contoh [sokuBAKU ]--> [baku] -->[bakkii]

e. Selain pemendekan dengan menghilangkan dan menggantikan bagian tertentu, ada pula dengan menambah atau mengubah berdasarkan karakter huruf tersebut. Sebagai contoh:

「死ぬ」 $\rightarrow$ 「死」 $\rightarrow$ 「夕」「ヒ」 $\rightarrow$ 「タヒる」

f. Selain mengubah berdasarkan karakter huruf tersebut, terdapat pula penggantian kata yang memiliki makna yang sama. Sebagai contoh [hitomebore] --> vichikyun [me ni amai] -->aikyandi

g. Kemudian ada pula pemendekan yang mengubah kata tersebut ke dalam romaji terlebih dahulu dan kemudian diambil silabel awalnya saja. Sebagai contoh [N anka Henna K anji] -->NHK

h. Sebagian besar kata yang muncul pada bangumi tersebut ditulis di dalam katakana. Hal ini karena sebagian besar daripada kata tersebut merupakan gairaigo. Selain itu alasan lain adalah penekanan terhadap kata tersebut yang dapat dikategorikan sebagai ingo (bahasa sandi) 
TAEH 2 HASLANALSS WAKAMONOKOTCBADALAM“NEMWCRDLLANSMAPXSMPP'

\begin{tabular}{|c|c|c|c|c|c|c|c|}
\hline No & ASAL KATA & $\begin{array}{l}\text { JUMLAH } \\
\text { SUKU } \\
\text { KATA } \\
\text { AWAL }\end{array}$ & PELESAPAN & PENGUBAHAN & PENAMBAHAN & $\begin{array}{l}\text { ABREVIASI } \\
\text { AKHIR }\end{array}$ & $\begin{array}{l}\text { JUMLAH } \\
\text { SUKU } \\
\text { KATA } \\
\text { AKHIR }\end{array}$ \\
\hline 1 & カラオケの友達 & 9 & オケーのー達 & & & カラ友 & 4 \\
\hline 2 & 赤外通信 & 8 & 外一通信 & & る & 赤る & 3 \\
\hline 3 & 被害妄想 & 7 & いーうー想 & & & ひがも & 3 \\
\hline 4 & 無理な夢 & 5 & なー夢（ドリ） & 夢 $\rightarrow$ ドリーム & & むりーム & 4 \\
\hline 5 & 束縛 & 4 & 束 & ばくーバッキー & & バッキー & 3 \\
\hline 6 & いたずらな告白 & 9 & ずらなー白 & いた $\rightarrow$ イタ & & イタ告 & 4 \\
\hline 7 & 妄想する & 5 & うーす & & & もそる & 3 \\
\hline 8 & ロデオ男 & 6 & オ & & & ロデ男 & 5 \\
\hline 9 & トライアングル & 7 & イーアーン & & & トラグル & 4 \\
\hline 10 & 魔性の女の子 & 8 & うーの女の & & & マショ子 & 3 \\
\hline 11 & ペコペコ & 4 & ペコ & & る & ペコる & 3 \\
\hline 12 & 切羽詰まってる & 8 & 詰まってる & 切羽 $\rightarrow$ キリバネ & & キリバネ & 4 \\
\hline 13 & なんか変な感じ & 9 & & $\begin{array}{l}\text { なんか(N)、変な } \\
(\mathrm{H}) 、 \text { 感じ(K) }\end{array}$ & & NHK & 3 \\
\hline 14 & 蟹に噛まれる & 7 & に一れる & & & カニカマ & 4 \\
\hline 15 & 一目惚れ & 5 & & $\begin{array}{l}\text { 一目惚れ } \rightarrow \text { 一き } \\
\text { Фうん }\end{array}$ & & 一きゆう & 5 \\
\hline 16 & エンジェル & 4 & & エン $\rightarrow \quad ¥$ & & ¥ジェル & 4 \\
\hline 17 & ミートグッドバイ & 7 & ド & & & $\begin{array}{l}\text { ミートグ } \\
\text { ッバイ }\end{array}$ & 6 \\
\hline 18 & コナンの逆 & 6 & の) & & & 逆コナン & 5 \\
\hline 19 & 死ぬ & 2 & ぬ & $\begin{array}{l}\text { 死 } \rightarrow \text { 「タ」 } \\
\text { 「ヒ」 }\end{array}$ & る & タヒる & 3 \\
\hline 20 & 寝不足 & 4 & & 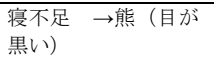 & る & くまる & 3 \\
\hline 21 & 目に甘い & 5 & に & 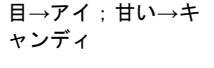 & & $\begin{array}{l}\text { アイキャ } \\
\text { ンディ }\end{array}$ & 5 \\
\hline 22 & 公衆弁所 & 7 & 衆 & 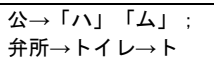 & & ハムト & 3 \\
\hline 23 & 髮が乱れる & 7 & & & る & 与謝野る & 4 \\
\hline 24 & 武田徹夜 & 6 & 徹夜 & & & 武田さん & 5 \\
\hline
\end{tabular}


i. Ditemukan pula penambahan mora yang dilakukan untuk menegaskan kata tersebut. Sebagai contoh pada kata [bakkii] 「バッキー」

j. Berdasarkan jenis kata berdasarkan penggunaannya, kata yang terdapat dalam bangumi ini sebagian besar dirubah ke dalam bentuk verba dan dapat mengalami perubahan bentuk seperti verba pada umumnya. Sebagai contoh [mosoru] --> mosochatta/ mosotteshimaimashita [tahiru] --> tahichau/ tahiteshimaimasu

i. Sesuai dengan kategori karakteristik dari Tanaka (dalam Sudjianto, 2007), pembentukan wakamono kotoba yang muncul dalam acara televisi $\mathrm{N}$ ew W ord Land SmapxSmap ini terdiri dari pemendekan kata (15 kata), sakasa kotoba/ pembalikan kata (1 kata), membuat verba (7 kata) dan mengaitkan dengan manusia (2 kata). Sisanya merupakan pembentukan berdasarkan modifikasi daripada simbol/ huruf dari kata asalnya.

\section{REKOMENDASI}

Karena keterbatasan penulis dalam waktu dan lain hal, masih terdapat banyak kekurangan dalam penelitian ini. Adapun penulis merekomen dasikan penelitian lebih lanjut mengenai:

a. Pengkategorian pembentukan wakamono kotoba dalam bahasa Jepang dalam konteks bahasa populer

b. Kontrastif antara pembentukan wakamono kotoba(bahasa gaul/ slang) dalam bahasa Indonesia dan bahasa Jepang

\section{DAFTAR PUSTAKA}

Chaer Abdul, Agustina Leonie (2010). Sosiolinguistik Perkenalan Awal. Jakarta: Rineka Cipta.

Ertina, M Erni (2010). Analisis Wakamono Kotoba pada Terebi Bangumi Haneru Tobira "Tanshuku Tetsudou no Yoru (Analisis Pemendekan Kata dalam Wakamono Kotoba) . Unpublished graduate thesis, UPI, Bandung.

Kuwamoto, Yuji. (1998). Ryakugo Keisei kara M ita Nihongo no Choujo Onsetsu no Kouzou ni Tsuite. Gengo Kagakuronshu, 2, 25-35.

Mulyati, Yeti. (2012). Menyoroti Abreviasi: Singkatan dan Akronim. Bandung:FPBS-UPI. Retrieved July 31, 2017, from Direktori File UPI database.

Rosidi, Ajip. (2010). Bahasa Gaul. Bandung: Pikiran Rakyat, Juni 5, 2010.

Sudjianto (2007). Bahasa Jepang dalam konteks sosial dan kebudayaannya Bandung:FPBSUPI. Retrieved July 31, 2017, from Direktori File UPI database. 